\title{
Analysis of Online Newspapers' Framing Patterns of COVID-19 in Nigeria
}

\section{Emmanuel Chike Onwe, PhD}

Department of Mass Communication, Ebonyi State University Abakaliki, Nigeria

Oasis Research Institute, 35 Afikpo road, Abakaliki, Nigeria

$$
\text { Joseph Chukwu, PhD }
$$

Department of Mass Communication, Alex-Ekwueme Federal University, Ndufu-Alike Ikwo, Nigeria Oasis Research Institute, 35 Afikpo road, Abakaliki, Nigeria

Samuel Chukwuemeka Nwamini, Simon Ugochukwu Nwankwo, PhD Stephen Elem, PhD

Nelson Iroabuchi Ogbaeja, PhD

Department of Mass Communication,

Ebonyi State University Abakaliki, Nigeria

Oasis Research Institute, 35 Afikpo road, Abakaliki, Nigeria

\section{Chinedu Jude Nwasum,} Ekwutosi Sanita Nwakpu,

Department of Mass Communication,

Alex-Ekwueme Federal University, Ndufu-Alike Ikwo, Nigeria Oasis Research Institute, 35 Afikpo road, Abakaliki, Nigeria

\section{Jude Nwakpoke Ogbodo, PhD}

Department of Mass Communication, Ebonyi State University Abakaliki, Nigeria

Oasis Research Institute, 35 Afikpo road, Abakaliki, Nigeria

Doi:10.19044/esj.2020.v16n22p217 URL:http://dx.doi.org/10.19044/esj.2020.v16n22p217

\begin{abstract}
Online newspapers have become one of the leading hubs for information disemination especially with the advent of web 2.0. Internet penetration in Nigeria has also contributed immensily in making diferent news contents avaliable on the web. Many people now depend on their smart phones, laptops and tablets to access news from the internet. Articles in online newspapers on COVID-19 are shared social media platforms such as Facebook, Twitter, WhatsApp, Instagram, Telegram amongst others, making
\end{abstract}


it possible for stories to easily go viral. The manner in which online newspapers frame issues of public importance determines the level of knowledge of online news consumers and their perception of the issues. This study investigates how three online newspapers framed the outbreak of COVID-19 pandemic in Nigeria. Anchored on Frame Analysis Theory, the study also employs Relational Content Analysis as its design. Finding shows that fear and death, government and/political influence, and palliative frames emerged as the dominant frames across the three online newspapers - Sahara Reporters, Premium Times and Daily Post studied for three months.The implication of this finding is that online newspapers reported COVID-19 outbreak in ways that made the audience jittery before the eventual outbreak of the pandemic. The study recommends that online newspapers should harp more on palliative as against fear and death frames in reporting any health emergancy in the future.

Keywords: COVID-19, Pandemic, Coronavirus, Online newspapers, Nigerian media, Framing

\section{Introduction}

The outbreak of coronavirus in December 2019, in Wuhan Province, China has created an avalanche of health issues and crisis for various media outlets to report. The European Centre for Disease Control (ECDC, 2020) reports that coronaviruses are a large family of viruses capable of causing severe illness in animals or humans. According to ECDC, the viruses are known to cause severe respiratory infection and other diseases such as Middle East Respiratory Syndrome (MERS), Severe Acute Respiratory Syndrome (SARS) and the coronavirus disease known as COVID-19. Regencia, Stepansky and Uras (2020) stated that a cluster of pneumonia cases of unknown aetiology was reported in Wuhan as the causative agent of the novel coronavirus. The outbreak of the pandemic has truly engaged media organizations in a reportorial contest since its emergence. Since the outbreak, the media (in all forms) have embarked on a reportorial spree to keep the public duly informed about the prevalence, fatalities and preventive measures. Such roles are the hallmarks of the media (Adegbija, Fakomogbon, and Adebayo, 2013).

The online newspapers were not left out in the coverage of the pandemic. The high number of deaths in countries like the United States, United Kingdom, Italy, Spain, and Brazil, has made the reportage of the novel pandemic a delight for many online newspapers all over the world. The COVID-19 news developed and spread across the world with online newspapers through their reporters anchoring their analysis on frames such as health infrastructural deficit, poverty, economy, politics and business. 
Providing news analysis anchored on various frames became the central focus of both conventional and online newspapers counterparts across the world. In the United State of America, Esposito (2020) reports that the coverage of COVID-19 has been inflammatory, particularly across social media and other unsubstantiated sources, which are unfortunately taken as facts. Fotheringham (2020) looked at the health angle of the fight against the pandemic and acknowledges that in Spain one of the most high-profile reasons on the situational analysis is the public health service's uneven and reportedly depleted resources for tackling this pandemic. Scott (2020) opines that the pandemic is already exposing inefficiencies and discriminations in the health system of USA.

In Nigeria, the index case of the pandemic was an Italian national who arrived the country on $28^{\text {th }}$ February, 2020 (Nigeria Centre for Disease Control - NCDC, 2020). Subsequently, the virus has continued to spread unabated in the country. In order to curb the spread of the virus, the Federal Government of Nigeria enforced a lockdown of Lagos state (the epicentre of the pandemic), Ogun State and the Federal Capital Territory (FCT). The approach adopted by online newspapers in reporting the pandemic in Nigeria has been met with what most communication researchers termed 'infodemic' (see Medford et al., 2020). Kazeem (2020) writes that in the coming days, as Federal and State government in Nigeria intensify effort to identify to contain the disease, the government will also be worried about the spate of misinformation trailing the outbreak. Online media outlets have adopted measures to satisfy the curiosity of their audiences by reporting all trajectories and effects of the pandemic. According to Tayimbe (2020), the virus has at the same time exposed the fecklessness of some political leaders and the incompetence of governments at all levels in the country.

Online newspapers are gradually becoming a popular means of information dissemination. As such, majority of Nigerians depend on online newspapers to access various information including the COVID-19 news. Expressing the importance of sourcing news online through the internet and its enabled tools, Philipp (2010) writes that the internet is fast becoming the dominant force in the information world; he further argues that it has transformed the ways in which information is aggregated, stored, searched, disseminated and retrieved. Extant literature has also acknowledged the constant growth and the rate of internet penetration in major cities in Nigeria. Olagide (2011) opines that the internet is the fastest growing medium of communication in human history. However, Chukwu (2004) also acknowledged that the availability of internet-enabled e-news is having negative influence on conventional media. Contributing, Russon (2020) explains that over 100 million Nigerians are now connected to the internet. It is evident that many Nigerians depend on the internet for most of their daily 
newsfeeds, especially as newspaper sales has predictably dropped following technological advances and indeed, the lockdowns imposed as countermeasures to contain the spread of the virus.

The media is known for its critical evaluation of issues such as COVID-19 outbreak to help the public understand concepts associated with news events. Framing a news story in the online newspapers can be influenced by different factors such as highlighting news angle that arouse reader's interest, economic motive of the reporter and competitive media debacle (Adelakun and Hamedi, 2017; Odoemenam and Okoro, 2013; Suleiman and Ojomo, 2019). The understanding of news frame from a handful of researchers look quite similar. According to Nsude, Onu, Nwamini and Nwofe (2016), news frames refer to the nuances, bias, opinions and meanings journalists introduce to stories with a view to breaking down complex reality for readers and viewers to assimilate.

Framing explains the power structure of the media to create news story items with predefined and narrow contextualization to enhance understanding or used cognitive shortcuts to link stories to the bigger picture (Oso, 2017). The implication of this submission is that the media can influence news content by subtle submission to downplay the perceived negative effect of the story on the general public by choosing a particular frame pattern. The media can also through choice of frame aggravate the supposed subtle effect to more dire consequences on the general public. In a similar way, Anyadike (2015) believes that the volume of report given to an issue in the media explains the public knowledge, understanding and perception on the issue.

\section{Statement of the Problem}

One of the essential services of mass media in critical situations of health challenges like the novel coronavirus pandemic, is to keep adequate surveillance of the event by regularly providing the public with updated information (Ogbodo et al., 2020). The media uses various available channels including the online platforms to inform, educate and sensitize the target audiences about the pandemic. Information on the pattern of frame, prevalent and dominant frames used by the online newspapers in framing coronavirus pandemic in Nigeria is empirically lacking. No known study in Nigeria has been able to fill this lacuna. A noble attempt to reduce this academic lapse/knowledge gap and provide empirical data for future researches, suffices for this study.

\section{Scope of the Study}

The scope of the study covers the period the case of coronavirus pandemic became predominant in Nigeria's media space, especially online newspapers. Therefore, the timeline for the study is from $1^{\text {st }}$ February to $30^{\text {th }}$ 
April, 2020, (three months). This was the period when reports of the outbreak peaked and became the major news headlines in Nigeria outlets. This was also the period government policies and programmes to contain the scourge became journalists' delight as they reported the pandemic in all media platforms. The study focused on three carefully selected online newspapers, Sahara Reporters, Premium Times, and Daily Post. The justification for the selection of these online newspapers hinges on the fact that they represent the leading online newspapers in Nigeria and there are known for in-depth news analysis on a wide-range of issues such as health and politics. Other factors include: up to date news, interactivity and user friendly site, effective feedback mechanism and use of cookies that allow all visitors to have the best experience surfing and reading news online.

\section{Research Objectives}

The general objective of this study is to analyse how three online newspapers framed the outbreak of coronavirus pandemic in Nigeria. Specifically, the study is meant to:

1. To explore the patterns of framing the coronavirus pandemic in Nigerian online newspapers.

2. To determine the dominant frames adopted by online newspapers in reporting the coronavirus pandemic in Nigria.

3. To ascertain how online newspapers' framing of the coronavirus pandemic compare in Nigerian online newspapers.

\section{Research Questionss}

1. What were the pattern of frames of coronavirus pandemic in Nigerian online newspapers?

2. What were the dominant frames of coronavirus pandemic in Nigerian online newspapers?

3. How do frames of the pandemic compare in Nigerian online newspapers?

\section{Frame Analysis}

This study adopted content analysis method. The choice for the adoption of this method is dependent on the subject matter of inquiry (Nwafor, Nwasum and Nkwuda, 2017). Adekunle and Hamide (2017) developed and adopted these frames: causes and transmission frame, fear and death frame, government/political influence frame and rumour and misinformation frame in their study with emphasis that journalists frame their stories on the outbreak of Ebola in line with its spread and effects on people and society at large. The preventive concept that constitutes media framing of the coronavirus outbreak in Nigeria within the period of the study of online newspapers were framed 
based on the prevailing circumstances in the country. These frames include: social distancing, lockdown, and palliative frames developed in this study to support the health emergencies frames used by Adekunle and Hamide (2017).

The essence of framing in content analysis is to clarify and understand the journalists' perspective, news sources and the context of the stories in relation to the subject matter (Burns, Richter and Kant, 2013). More so, journalists' interpretation of disease outbreak and its attendant effect on people and society constitute the bases for appropriate content analysis and news frames of online newspapers. The adopted frames reflected online newspaper perspective, views and editorial stands on visible realistic public views, opinions, attitudes and reactions toward the outbreak of COVID-19 in Nigeria. The COVID-19 scourge in Nigeria provoked and attracted serious public attention on its causes, transmission, treatment, containment, fear and deaths as well as government/political influence, management of misinformation, social distancing, lockdown and palliatives to cushion the effect of the pandemic in Nigeria.

\section{Literature Review}

There is no doubt to the fact that the outbreak of the rampaging coronavirus dubbed COVID-19 took the world aback. As highlighted earlier, conspiracy theorists believe that the dreaded virus escaped from the Wuhan Medical Laboratory in China, but scientists warn against such beliefs (Calisher et al., 2020). At first, the virus got hold of the Wuhan city and later spread to other parts of the world like wild fire. As the world woke up to the harsh reality of combating the dreaded virus, so many questions needed to be answered, and many more are propping up. For instance, the world needed to know how the Chinese Government and the World Health Organisation (WHO) handled the outbreak in the first time. So many questions about the medical chemistry of the virus, its modes of transmission, incubation period, life span, environmental adaptation and many more needed urgent informed answers. Consequently, many conspiracy theorists have emerged to add to the conflicting narratives about the virus (Ogbodo et al., 2020; Nwakpu, Ezema and Ogbodo, 2020). Fortunately, online newspapers at the global, regional and national levels have taken up their traditional responsibility of creating awareness, educating, sensitizing and mobilizing people against the pandemic. Indeed, it suffices to say that the world is relying on the media for a must-win war against the virus. This implies high expectations of social responsibility from the media organisations as they frame the messages about COVID-19 pandemic. "The mass media cannot cure the attack of Ebola virus disease (EVD), but can cure its spread" (Adelakun and Adnan, 2016, p. 3202). Earlier on, Anyadike (2015) had cited Anyanwu (2004) and Ohaja (2005) as saying that whatever the audience makes of media information or messages is 
determined by the way and manner such messages and information are mediated or framed and disseminated to them (see also, Suleiman and Ojomo, 2019).

Empirical studies have indicated that media have the potentials to prevent the spread of infectious diseases by encouraging good personal and public health practices. In their study of the influence of radio Lassa fever messages on the residents of rural communities of Ebonyi State, Nwankwo and Orji-Egwu (2017) maintain that media message frames are critical to the people's dispositions towards public health campaigns, and their eventual acceptance or rejection of such campaigns. According to them, the frames can give hope as well as create fear or apathy in the people. Consequently, Nwankwo and Orji-Egwu (2017) found that the Lassa fever radio campaign message clashed with the cultural belief and values of the people; thus, the failure of the campaign to stop the people from eating rats in parts of the state. In an earlier study, Kogah and Nwadiaro (2016) also suggest that Wall street Journal of January 2016 story by Gbenga Akingbule gave hope to Nigerians by stating that Lassa fever is more benign than Ebola virus and that only about $1 \%$ of Lassa virus infected persons die from the illness. They also reported that their second finding suggests that Vanguard, Premium Times and Saturday Punch were respectively professional in their reportage of the outbreak in the country.

By and large, studies on media frames thrive highly on the principles of scientism/ empiricism. Frame study should not be subjective and judgemental. Manifest contents must be reduced into realistic variables for systematic investigation. As such, Ezegwu, Ezeonyejiaku and Asodike (2018) announced that their study on newspaper framing of Monkey pox outbreak in South-Eastern states of Nigeria was aimed at ascertaining the genre of the story, the prominence, kind of frames, dominant frames and influence of the frame on the people. To execute the study; Guardian, The Punch and Vanguard were purposively selected for the period of September $1^{\text {st }}$ to December $31^{\text {st }} 2017$. The results from the mixed research methods (content analysis and survey) show that the newspapers used the straight news format most in reporting the outbreak, the outbreak was given prominence, especially in terms of placement, the transmission/causes frames was the most dominant and this raised fear in the Nigeria media audience. However, the analysis of media frames (newspapers) is dependent on the objective (s) of the study. Media message frames can be probed on the basis of people's expectations of role played by the government, people or agencies and media biases in favour or against a certain issue, government, institutions, person or persons. Asaolu, Iwu, Ifiheh and Osayande (2016) reveal that their investigation of the newspaper coverage of Ebola virus outbreak in Nigeria shows that the dominant theme or focus of the papers (24.1\%) was government, and 
institutional measures/responses to the outbreak. This was followed by the news report on cases of outbreak in parts of Nigeria. They concluded that newspaper reportage of the Ebola outbreak had implication for its prevention and control. Similarly, Fawole, Thomas and Ibitade (2012) had reported that their study of the media reportage of outbreak of avian influenza in Nigeria shows that all the selected newspapers stressed public awareness, industry crisis, and government responsibility in tackling the outbreak.

From the foregoing discussion, it can be inferred that media frames of outbreak of diseases are reflections of multifaceted factors that impinge on the editorial policies, values and activities of each media outlet especially online newspapers. These intervening factors include, but not limited to ownership influence, economic and political interest, culture, legal framework and professional competence. For example, Adelakun and Adnan (2016) studied the framing of Ebola virus outbreak in Nigeria by The Sun and The Guardian newspapers between July 20 and Oct. 20 2014. In the course of the study, they looked at the following dominant frames: cause and transmission, treatment and control/containment, fear and death, government and political influence, effect, sensitization/mobilization, consolation and support, rumour/misinformation and stigmatization/discrimination. Furthermore, Adelakun and Adnan (2016) also identified the following as factors that shaped the newspapers' framing of the outbreak: organisational pressure/constraints, social norms, journalistic routines, pressures from interest groups, ideological and political orientation of the journalists, editorial policy and ownership influence. In conclusion, the authors found that framing of Ebola outbreak by the Nigerian national dailies was significantly influenced by economic and political motives aggravated by the stiff competition in the industry.

Drawing inspiration from the above researches, this study is interested in probing the online newspapers' framing of the current outbreak of the novel coronavirus. The quest for this investigation is further heightened by the number of conspiracy theories dotting the attempt to figure out the variegated issues surrounding the pandemic both at the national and global levels. As the doubt among many Nigerians about the realistic existence of COVID-19 in the country gave way for personal and public containment measures as championed by the government, the agonies of either partial or full lockdown in parts of the country followed. As the lockdown cast the majority of Nigerians with the double jeopardy of COVID-19 and "HungerVid-20", the prudent management of the emergency fund realised for the battle and transparent distribution of palliatives became louder. Also added to the plenteous salient issues competing for the attention of the online newspapers in their coverage of the outbreak was the alleged China-centric posture of the Federal Government of Nigeria in the search for solution and the political 
intrigues and local efforts of the respective state governors and supervisory role of the Nigerian Centre for Disease Control (NCDC).

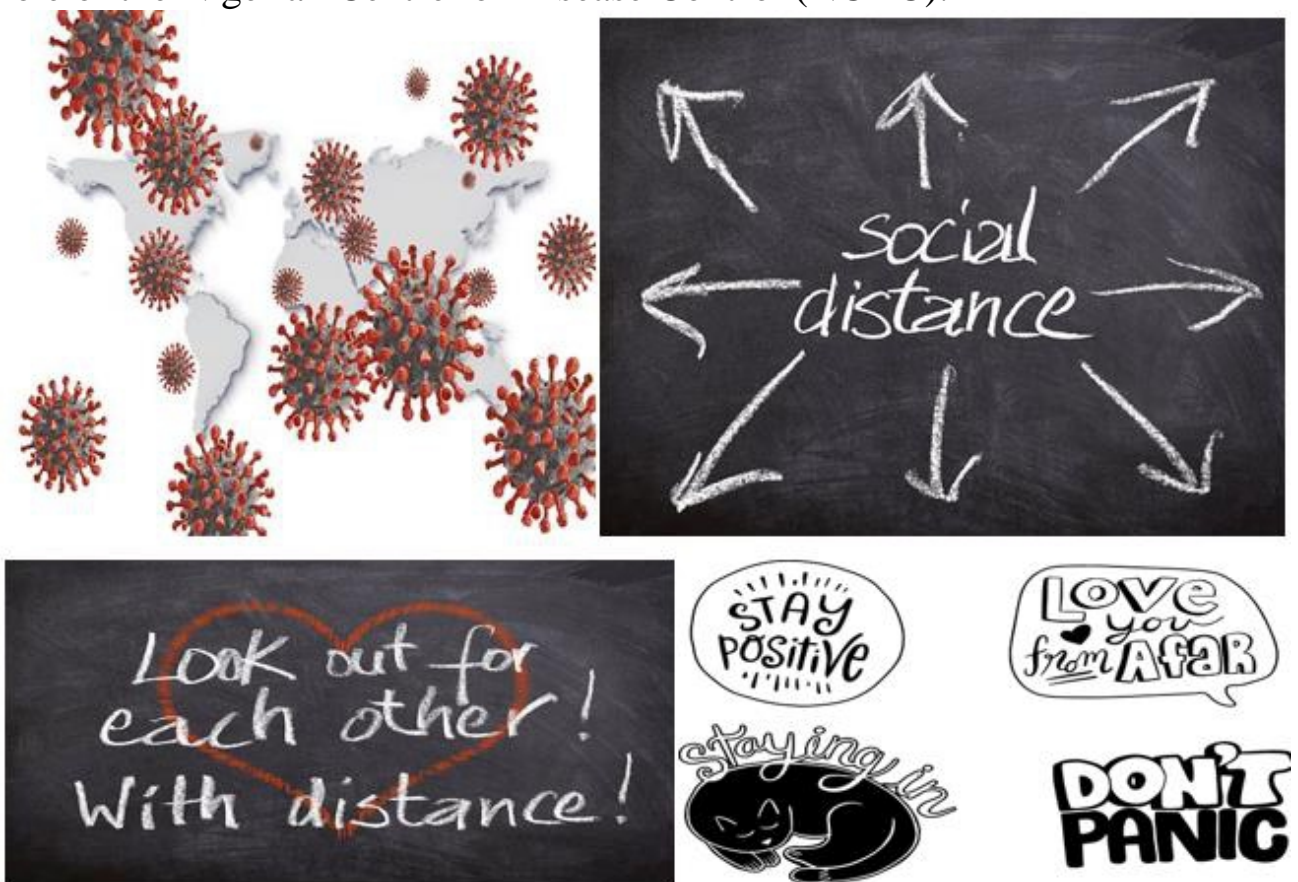

Figure 1: Guideline Images on how to Stay Safe during the Lockdown by Online Newspapers in Nigeria

Ogundola (2013) favours an empirical investigation of the Nigerian media reportage of the pandemic as his finding suggests that newspapers often employ stereotypically offensive language when reporting disability stories. According to him, media frames that emphasise frailty, charity, disparity and derogatory labels leave room for stereotypes, prejudices and stigmatization of people living with disability in Nigeria. Anyadike (2015) in another study observed that newspapers coverage of the Nigerian Governor's Forum election crisis failed to promote peace building process but encouraged the crisis.

The irony is that in times of crisis or outbreak of dreaded epidemic or pandemic as being experienced now, the media/press becomes the "watcher" and the "watched". Nigerians expect the press especially the online newspapers to educate them on how to avoid contracting the Coronavirus ranging from proper hand washing and use of hand sanitizer, putting on face mask in public places to social distancing as shown in the above pictures. Besides, the press should give Nigerians information on how to access food aid/palliatives from the governments, agencies and individuals, and as well, the number of infected persons, the dead and recoveries. As part of its social responsibilities, the media can extend its report to investigating government 
spending and ensure equitable distribution of palliatives to the vulnerable persons. On the other hand, Adelakun and Adnan (2016) say that the Nigeria press watches the governments and the people's compliance to NCDC laid down rules, regulations and protocols on the containment of the virus. This is in addition to monitoring of governments' responsiveness, actions, transparency, prudence and diligence in handling the crisis situation. All these and others are easily ascertained through systematic investigations as exemplified by this study.
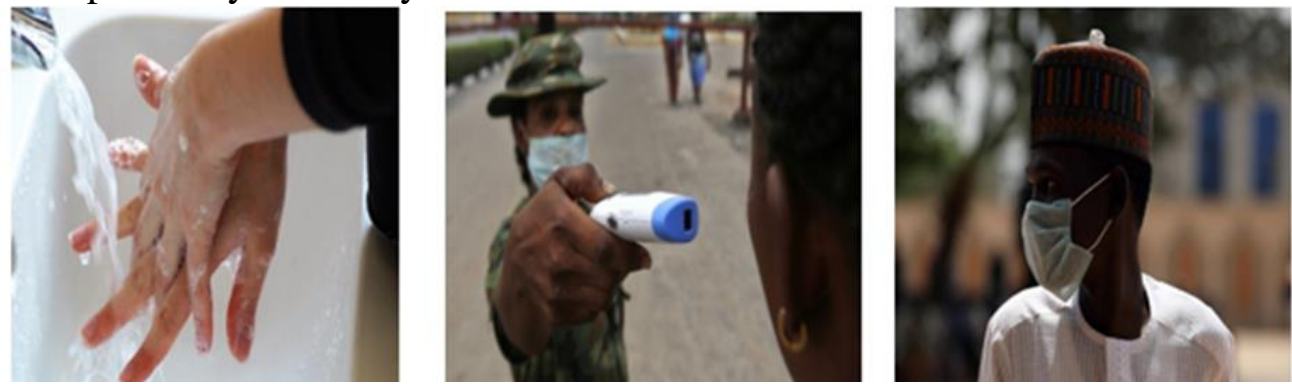

Figure 2: Online Newspapers' Images on the Preventive Guidelines

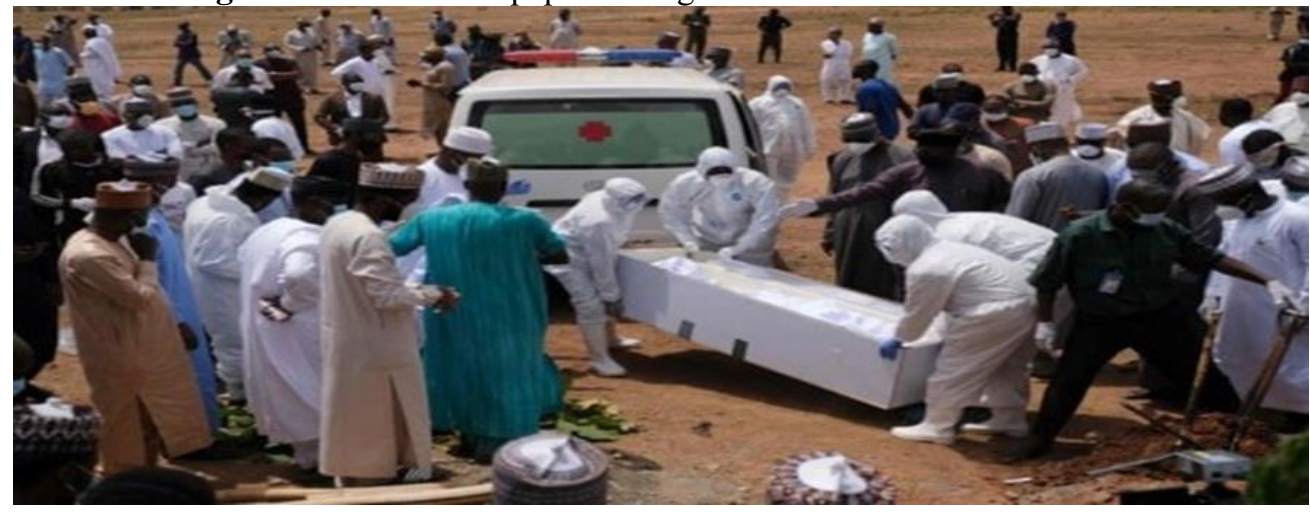

Figure 3: Online Newspaper's Image during the Burial of the late Chief of Staff to

President, Abba Kyari one of the Victims of the Virus. Source: Kola Sulaiman /AFP

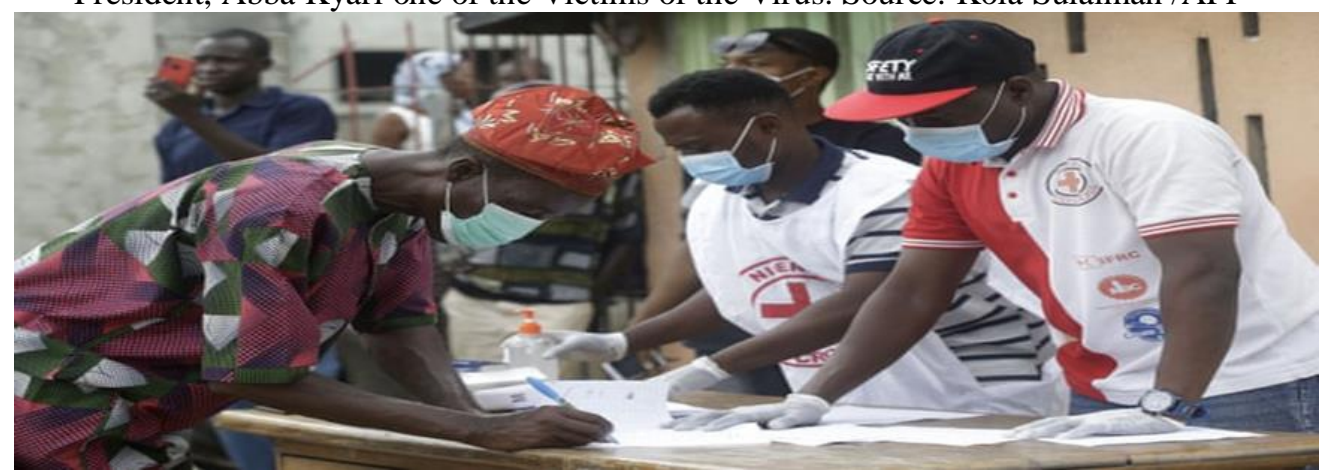

Figure 4: Online Newspapers' Image Depicting Food/Aid Distribution by Red Cross to Lagos Residents who are Victims of Hunger as a result of Complete Lockdown. Source: Sunday Alamba/ AFP 


\section{Theoretical Framework}

The study is anchored on Framing Theory. This theory is believed to have been popularised by Erving Goffman in 1974 (Scheufele, 1999). Frame theory is an expansion of the agenda setting theory of the press. The theory, besides accepting that the media focuses attention on certain issues they consider topical and thereby drawing the attention of the masses to it, also posits that the way, manner and language with which such issue is presented to the masses largely influence the masses perception of it (Ogbodo, 2018). In essence, framing theory opined that how a matter is presented to the audience influences the choices they make about such a subject matter (Goffman, 1974).

The theory suggests that people interpret what is going on around their world through their primary framework. According to Goffman (1974), these primary frames are made up of natural and social frames through which an individual is able to interpret the communication stimuli coming his way on a daily basis. The theory, according to Scheufele (1999), makes four major assumptions: journalists select the topics they will present and still bear the professional responsibility of deciding how the selected topics would be presented to the audience. This means that framing theory believes that the media not only determines the issues audience think about but also influences how the audience think about the issue; and interpret information through their own frame. Audience frames may overlap or contradict the media frames, media frames are reinforced every time they are evoked, whether positively or negatively and frame building is a systematic process that occurs over time.

Therefore, frame is simply the way a communication source defines and constructs any piece of communicated information or message with a view to subtly swaying the mind of the audience towards a predetermined sentiment. The theory is relevant to this study because the framing of online newspapers on Covid-19 is a major factor that can either make or mar the individual and collective efforts to contain the virus in Nigeria.

\section{Method of study}

This study adopted relational content analysis method. Relational content analysis examines relationships amongst concepts in a text by exploring how individual meanings directly relate and depend on the other (Owen, 2012). This method is used to analyse manifest contents of public informed issues with a view to unveiling their extant pattern in the three selected online newspapers (Sahara Reporters, Premium Times, and Daily Post). These three online newspapers were selected purposively. Although they were selected purposively, they feature high readership on variety of issues that appeal to both the elite and popular classes. In view of their analytical approach to different issues in the country, they are more likely to provide extensive coverage of the coronavirus pandemic. Because of the 
volume of the publication in each of the selected online newspapers, the researchers adopted simple random sampling technique and selected three working days in a week (Mondays, Wednesdays and Fridays) to extract online articles on coronavirus from the websites of the selected online newspapers.

On the other hand, the quantitative approach involved the application of numeric (numbers) values to collate, analyse and present data through monitoring and extraction of COVID-19 news articles in the selected online newspapers. All articles with stories on the pandemic were downloaded, saved, printed and coded in sequence in each of the selected days (Mondays Wednesdays and Fridays) to examine the pattern, dominant and prevailing frames in the entire COVID-19 related articles. Statistical tools like SPSS, frequency, percentage and charts were used for the data analysis. The qualitative data collected were also presented in discourse analysis research method or technique. These approaches aided maximum actualization of the objectives and production of valid results.

The sample size for this study was determined by adopting the composite week procedure of Riffe, Aust and Lacy (1993), in their words, "a composite week sampling procedure is superior to both a random sample and a consecutive day sample when dealing with newspaper content." The articles on COVID-19 from each of the online newspapers for the three months understudy were grouped according to the selected days, weeks and months. In each of the selected days, all articles on COVID-19 per online newspaper were collated and divided using average mean value of all the selected COVID-19 articles per week to cover the entire articles published by the online newspapers. Holsti's inter-coder reliability formula was used to determine the reliability of the coding system. The inter-coder reliability showed coefficient reliability of 0.82 . The tables below show the method of selecting number of articles from three online newspapers under study.

\section{Data Presentation}

Table 1: Showing the Number of Selected Articles on COVID-19 Pandemic from the Websites of the Online Newspapers for the month of February, 2020

\begin{tabular}{cccc}
\hline $\begin{array}{c}\text { Selected online } \\
\text { newspapers }\end{array}$ & $\begin{array}{c}\text { No of Articles per } \\
\text { selected days }\end{array}$ & $\begin{array}{c}\text { No of Articles } \\
\text { per Week }\end{array}$ & $\begin{array}{c}\text { No of Article } \\
\text { per Month }\end{array}$ \\
\hline Sahara Reporters (SR) & 3 & 9 & 36 \\
Premium Times (PT) & 2 & 6 & 24 \\
Daily Post (DP) & 2 & 6 & 24 \\
Total & $\mathbf{7}$ & $\mathbf{2 1}$ & $\mathbf{8 4}$ \\
\hline
\end{tabular}


Table 2: Number of Selected Articles on COVID-19 Pandemic from the Websites of the Online Newspapers for the month of March, 2020

\begin{tabular}{cccc}
\hline $\begin{array}{c}\text { Selected online } \\
\text { newspapers }\end{array}$ & $\begin{array}{c}\text { No of Articles per } \\
\text { selected days }\end{array}$ & $\begin{array}{c}\text { No of Articles per } \\
\text { Week }\end{array}$ & $\begin{array}{c}\text { No of Article } \\
\text { per Month }\end{array}$ \\
\hline Sahara Reporters (SR) & 4 & 12 & 48 \\
Premium Times (PT) & 2 & 6 & 24 \\
Daily Post (DP) & 3 & 9 & 36 \\
Total & $\mathbf{9}$ & $\mathbf{2 7}$ & $\mathbf{1 0 8}$ \\
\hline
\end{tabular}

Table 3: Number of Selected Articles on COVID-19 Pandemic from the Websites of the Online Newspapers for the month of April, 2020

\begin{tabular}{cccc}
\hline $\begin{array}{c}\text { Selected online } \\
\text { newspapers }\end{array}$ & $\begin{array}{c}\text { No of Articles per } \\
\text { selected days }\end{array}$ & $\begin{array}{c}\text { No of Articles } \\
\text { per Week }\end{array}$ & $\begin{array}{c}\text { No of Article } \\
\text { per Month }\end{array}$ \\
\hline Sahara Reporters (SR) & 4 & 12 & 48 \\
Premium Times (PT) & 5 & 20 & 80 \\
Daily Post (DP) & 3 & 9 & 36 \\
Total & $\mathbf{1 2}$ & $\mathbf{4 1}$ & $\mathbf{1 6 4}$ \\
\hline
\end{tabular}

Tables 1, 2 and 3 above show the sampling selection process of all published COVID-19 articles in the selected months (February, March and April, 2020). A total of 84 COVID-19 articles were systmetically selected using average mean value of all published articles in the month of February, 2020. SR published ( $n=36)$ COVID-19 articles while PT and DP had $(n=24)$ COVID-19 articles each. The tables above show that SR was more active in the month of February in covering coronavirus pandemic outbreak in Nigeria. In the month of March, 2020 a total of 108 COVID-19 articles were published by the selected online newspapers (Sahara Reporters, Primum Times and Daily Post). SR and DP showed more active responses, judging by the number of COVID-19 articles published by them; SR $(n=48)$, DP $(n=36)$ respectivly. The statistics depicts that as the virus keeps spreading in Nigeria, there are spikes in the publication of COVID-19 articles among the selected online newspapers. The result of the COVID-19 published articles in the month of April shows no exceptions, the spike in the volume of COVID-19 published articles is evident in the month of April with a total of $(n=180)$ published COVID-19 articles, while PT recorded the highest volume of COVID-19 published articles $(n=80)$.

\section{Research questions-based data analysis}

The data gathered in the course of this study were presented in line with the research objectives and questions.

RQ1: What were the patterns of framing the coronavirus pandemic in Nigerian online newspapers? 
Table 4: Patterns of Frames of online Newspaper Articles on COVID-19 for the month of February

\begin{tabular}{lcccc}
\hline Pattern of Frames on COVID-19 & SR $(\mathbf{n = 1 3 2})$ & PT(n=128) & DP $(\mathbf{n = 9 6})$ & $\begin{array}{l}\text { CU } \\
(\mathbf{N = 3 5 6})\end{array}$ \\
& & & & SR,PT\&PD \\
\hline Causes and transmission frame & $22(16.7 \%)$ & $21(16.4 \%)$ & $18(18.8 \%)$ & $61(17.1 \%)$ \\
Fear and death frame & $35(26.5 \%)$ & $31(24.2 \%)$ & $24(25.0 \%)$ & $90(25.3 \%)$ \\
Government/political influence frame & $28(21.2 \%)$ & $21(16.4 \%)$ & $14(14.6 \%)$ & $63(17.7 \%)$ \\
Rumour and misinformation frame & $10(7.6 \%)$ & $14(10.9 \%)$ & $10(10.4 \%)$ & $34(9.6 \%)$ \\
Social distancing frame & $10(7.6 \%)$ & $16(12.5 \%)$ & $11(11.5 \%)$ & $37(10.4 \%)$ \\
Lockdown frame & $12(9.1 \%)$ & $13(10.2 \%)$ & $10(10.4 \%)$ & $35(9.8 \%)$ \\
Palliative frame & $15(11.4 \%)$ & $12(9.4 \%)$ & $09(9.4 \%)$ & $36(10.1 \%)$ \\
Total & $\mathbf{1 3 2}(\mathbf{1 0 0 \%})$ & $\mathbf{1 2 8}(\mathbf{1 0 0 \%})$ & $\mathbf{9 6}(\mathbf{1 0 0 \%})$ & $\mathbf{3 5 6 ( 1 0 0 \% )}$ \\
\hline
\end{tabular}

Table 4 above indicates that the online newspapers selected for this study: SR, PT and DP, published these volumes of COVID-19 articles $(n=132),(n=128)$ and $(n=96)$ in their websites respectively for the month of February, 2020. Fear and death frames appeared 35 times in SR (26.5\%), PT recorded 31 COVID-19 articles $(24.2 \%)$, while DP had a total of 24 stories with $(25.0 \%)$ of COVID-19 articles. The dominance of the fear and death frame as seen in the above table is an indication that the online newspapers focused more on stories that caused panic among the public while undermining other aspects of the pandemic. The second highest frame is government/political influence frames with the cumulative total articles of (63, $17.7 \%)$ across all selected online newspapers (SR, PT and DP). SR ( $\mathrm{n}=28$, $21.2 \%)$, PT $(\mathrm{n}=21,16.4 \%)$ and DP $(\mathrm{n}=14,14.6 \%)$. Prompt decisions by various heads of government all over the world truly helped in mitigating the negative impact of COVID-19. However, Ifijeh (2020) reported that despite the looming trouble posed by coronavirus, the Nigerian government waited until the outbreak surged before issuing a strong travel ban. The causes and transmission frame ranked third in the order of prevalence in the coverage. As the table shows social distancing and palliative frames were relegated to the background. This implies that the newspapers emphasised the negatives more than the positive aspects of the coverage.

RQ2: What were the dominant frames of the coronavirus pandemic in Nigeria online newspapers? 
Table 5: Dominant Frames of online Newspaper Articles on COVID-19for the month of March

\begin{tabular}{lcccc}
\hline Pattern of Frames on COVID-19 & SR $(\mathbf{n = 1 3 2})$ & PT(n=128) & DP $(\mathbf{n = 9 6})$ & $\begin{array}{l}\text { CU of } \\
\text { (N=356) }\end{array}$ \\
\hline Causes and transmission frame & $05(3.8 \%)$ & $09(7.0 \%)$ & $08(8.3 \%)$ & $22(6.2 \%)$ \\
Fear and death frame & $35(26.5 \%)$ & $37(28.9 \%)$ & $26(27.1 \%)$ & $98(27.5 \%)$ \\
Government/political influence frame & $28(21.2 \%)$ & $21(16.4 \%)$ & $16(16.7 \%)$ & $65(18.3 \%)$ \\
Rumour and misinformation frame & $04(3.0 \%)$ & $08(6.3 \%)$ & $06(6.3 \%)$ & $18(5.1 \%)$ \\
Social distancing frame & $09(6.8 \%)$ & $10(7.8 \%)$ & $06(6.3 \%)$ & $27(7.6 \%)$ \\
Lockdown frame & $41(31.1 \%)$ & $35(27.3 \%)$ & $30(31.2 \%)$ & $106(29.8 \%)$ \\
Palliative frame & $10(7.6 \%)$ & $08(6.3 \%)$ & $04(4.1 \%)$ & $20(5.6 \%)$ \\
Total & $\mathbf{1 3 2}(\mathbf{1 0 0 \%})$ & $\mathbf{1 2 8}(\mathbf{1 0 0 \%})$ & $\mathbf{9 6}(\mathbf{1 0 0 \%})$ & $\mathbf{3 5 6}(\mathbf{1 0 0 \%})$ \\
\hline
\end{tabular}

As shown on table 5 above, SR published a total of ( $\mathrm{n}=132)$ COVID19 articles, PT $(\mathrm{n}=128)$, and DP ( $\mathrm{n}=96)$ COVID-19 articles published in the month of March. Lockdown frames became the dominant frames across the three online newspapers sampled with SR $(n=41,31.1 \%)$, PT $(n=35,27.3 \%)$ and DP $(n=30,31.2 \%)$ showing the cumulative number of published 106 articles for the month under review. Fear and death frames were second most dominant frame with a total of 98 COVID-19 articles. PT ( $\mathrm{n}=37,28.9 \%)$ recorded the highest number of published COVID-19 articles followed by SR $(\mathrm{n}=35,26.5 \%)$ and DP $(\mathrm{n}=26,27.1 \%)$. The influence of fear and death which characterised the preceding month largely reflected the media agenda in the following month as shown in the table above.

\section{RQ3: How do frames of the pandemic compare in Nigerian online newspapers?}

Table 6: Frames of the pandemic compared in Nigerian online newspapers

\begin{tabular}{lcccc}
\hline Pattern of Frames on COVID-19 & SR $(\mathbf{n = 1 3 2})$ & PT(n=128) & DP $(\mathbf{n = 9 6})$ & $\begin{array}{l}\text { CU of SR,PT\&PD } \\
\text { (N=356) }\end{array}$ \\
\hline Causes and transmission frame & $10(7.6 \%)$ & $04(3.1 \%)$ & $02(2.1 \%)$ & $12(3.4 \%)$ \\
Fear and death frame & $15(11.4 \%)$ & $10(7.8 \%)$ & $11(11.5 \%)$ & $34(9.6 \%)$ \\
Government/political influence frame & $14(10.6 \%)$ & $14(10.9 \%)$ & $10(10.4 \%)$ & $38(10.7 \%)$ \\
Rumour and misinformation frame & $06(4.5 \%)$ & $08(6.3 \%)$ & $06(6.3 \%)$ & $16(4.5 \%)$ \\
Social distancing frame & $36(19.7 \%)$ & $28(21.9 \%)$ & $19(19.8 \%)$ & $77(21.6 \%)$ \\
Lockdown frame & $30(22.7 \%)$ & $30(23.4 \%)$ & $20(20.8 \%)$ & $82(23.0 \%)$ \\
Palliative frame & $31(23.5 \%)$ & $34(26.6 \%)$ & $28(29.2 \%)$ & $97(27.2 \%)$ \\
Total & $\mathbf{1 3 2}(\mathbf{1 0 0 \%})$ & $\mathbf{1 2 8}(\mathbf{1 0 0 \%})$ & $\mathbf{9 6}(\mathbf{1 0 0 \%})$ & $\mathbf{3 5 6}(\mathbf{1 0 0 \%})$ \\
\hline
\end{tabular}

Table 6 above shows how these frames compare among the three online newspapers. As the above table demonstrates, the newspapers showed incongruences in framing causes and transmission of COVID-19. Thus, while Sahara Reporters dedicated $7.6 \%$ of its stories of the pandemic to causes and transmission, Premium Times and Daily Post only had 3.1\% and 2.1\% respectively on the causes and transmission. However, there was a near- 
identical framing of fear and death between two of the three online newspapers. As the table indicates, Sahara Reporters had $11.4 \%$ while Daily Post had $11.5 \%$. On the other hand, Premium Times differed with only $7.8 \%$ respectively on the fear and death frame. Another identical frame pattern was also observed in the framing of Government/political influence. In this instance, both Sahara Reporters and Premium Times recorded 10.9\% apiece while Daily Post dedicated $10.4 \%$ of its content to the Government/political influence frame. In rumour and misinformation frame Premium Times and Daily Post showed congruence while Sahara Reporters was slightly incongruent with just $4.5 \%$. In social distancing frame, Sahara Reporters and Daily Post also showed high congruence as both of them have $19.7 \%$ and $19.8 \%$ reports respectively on this issue. On the other hand, Premium Times had a slightly higher frames of $21.9 \%$ more than the rest. Inconsistency can also be observed in how the three newspapers framed lockdown. While Sahara Reporters account had 22.7\%, Premium Times recorded $23.4 \%$ and Daily Post recorded $20.8 \%$. Discrepancy in the framing pattern was also observed in the framing palliatives. Thus, while Sahara Reporters recorded $23.5 \%$ of palliative frame, Premium Times and Daily Post recorded 26.6\% and 29.2\% respectively. Cumulatively, palliative frame recorded the highest COVID-19 articles with 97 articles followed by lockdown frame with 82 COVID-19 articles while social distancing had 77 COVID-19 articles.

Figure 4: Showing Selected Online Newspapers Volume of Publications during the Months under Review

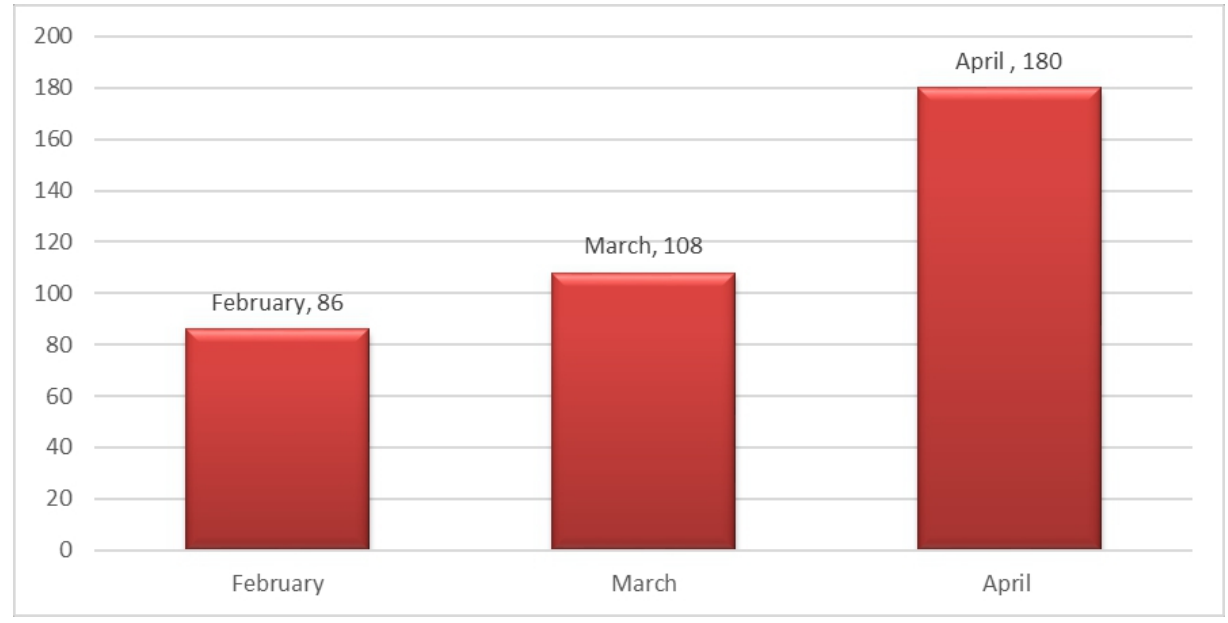

Figure 4 above shows the trajectory of COVID-19 published articles in the selected online newspapers in Nigeria. In the month of February, a total of 86 COVID-19 articles were published. COVID-19 articles published in April was 180 articlesand was higher when compared with 108 articles in March. The spike on the volume of publication by the online newspapers can be attributed to wide spread of the virus to many parts of the world. They also 
reported the outbreak considering various other angles such aseconomy, social interaction, politics, human interest, health infrastructure decay etc. These might help to the upsurge of articles on COVID-19 in Nigerian online newspapers.

\section{Discussion of Findings}

The study discovered different patterns of frames used by the reviewed online newspapers in Nigeria on the coverage of COVID-19 pandemic. The first month of the study shows Sahara Reporters, Premium Times and Daily Post emphasising fear and death frames with 35, 31 and 31 on COVID-19 across the three online newspapers studied. The implication is that during the first month of the study, online news platforms featured more hard news of deaths from countries attacked by the virus. Countries like China, Italy, Spain, United States and Germany recorded deaths before the pandemic spread to Nigeria.

In terms of how frames compare in online newspapers, our study shows that newspapers demonstrated both congruence and incongruence at varied proportions. While incongruences were demonstrated in framing the causes and transmission of COVID-19, lockdown and palliative frames, the three online newspapers were more congruent in framing fear and death. Another congruence among the three newspapers was evident in framing Government/political influence. In this instance, all the newspapers had $10 \%$. Premium Times and Daily Post also showed congruence in framing rumour and misinformation frame while Sahara Reporters was somewhat incongruent. The government's directive to lockdown the country to control the spread of the pandemic must have given rise to the need of and emphasis on palliative to be able to provide food for the vulnerable masses who depend on daily jobs from the informal sectors survive. The social responsibility of the media (online newspapers) as the conscience of the people has continued to highlight the consequences of the lockdown and emphasized the need for palliatives to enable the citizens survive the lockdown directive by the government.

\section{Conclusion}

The findings of this study have revealed the extent to which online newspapers contributed in the coverage and reportage of the outbreak of COVID-19 in Nigeria. This was made possible through the outcome of frame categories identified and adopted for proper understanding and interpretation of the COVID-19 coverage. In view of that, this study concludes that the outbreak of coronavirus in Nigeria which has brought fear and death to the citizens led to the introduction of preventive and protective measures by the government and other concerned health agencies like WHO and NCDC through the Federal Government of Nigeria to outline measures such as social 
distancing, lockdown and distribution of palliatives to the citizens to cushion the effects of coronavirus in the country.

The study further concludes that the reviewed online newspapers (Sahara Reporters, Premium Times and Daily Post), adopted causes and transmission, fear and death, government/political influence, rumour and misinformation frames in the reportage of the outbreak of COVID-19 in Nigeria at varied proportions. The authors developed and adopted three other frames - social distancing, lockdown and palliative frames which was used by authorities to regulate the spread of the virus. It is important to state that the online newspapers foregrounded the negative frames (such as fear and death, causes and transmission) more than the positive frames (such as palliatives and social distancing). The pandemic itself has caused enough stir globally, the media cannot afford to add to the atmosphere of fear, death and conspiracy that characterises this period. Instead, the media should find a way to report the issues constructively without adding to the public worries. The study further revealed that the spread of the virus continued to increase in each month as shown in figure 4 above. In the month of February, fear and death frames dominated news reportage of the selected online newspapers; Sahara Reporters, Premium Times and Daily Post. The frame categories from the three newspapers also indicate degrees of congruencies and incongruencies that characterised the choice of frames analysed in the study.

\section{Recommendation}

The study recommends that online newspapers should resist the temptation of focusing mainly on the negatives as such method may result in more fear and death among the public. As research has demonstrated, fear can kill faster than the virus. Therefore, the media (in all forms) should engage constructive coverage that balances the negatives and positives in equal proportions. For instance, the palliative frame can be reported in the same way fear and death frame dominated the coverage. This would ensure that online newspapers frame any health emergencies without creating unnecessary panic in the people some of whose underlying health problems may be complicated by fear associated with media framing of the pandemic.

\section{References:}

1. Adegbija, M., Fakomogbon, M., \& Adebayo, M. (2013). Roles of broadcast media for instructional delivery in open and distance learning: Nigeria as a case study. European Scientific Journal, ESJ, 9(23). https://doi.org/10.19044/esj.2013.v9n23p\%p.

2. Adelakun, L.A, \& Hamedi, M.A. (2017). Communication health: Media framing of ebola outbreak in Nigerian newspapers. Available at www.researchgate.net, accessed, $24^{\text {th }}$ April, 2020. 
3. Adelakun, L. \& Adnan, H. (2016). Communicating health: Media framing of Ebola outbreak in Nigerian newspapers. Journal Komunikasi: Malaysian Journal of Communication, 32(2). Doi: 10.1757/jkmjc-2016-3202-19.

4. Anyadike, D. O. (2015). Analysis of newspaper framing of the Nigerian Governors' forum election crisis of 2013. Mediterranean Journal of Social Science, 6(6), 315-327. Doi: 10.5901/mjsss.2015.v6n6scp315.

5. Asaolu, A. O., Iwu-James, J., Ifijeh, G. \& Osayande, O. (2016). Newspaper coverage of Ebola virus disease epidemic in Nigeria: Implications for prevention and control. The International Journal of Communication and Health, 10, 53-58.

6. Calisher, C., Carroll, D., Colwell, R., Corley, R.B., Daszak, P., Drosten, C., Enjuanes, L., Farrar, J., Field, H., \& Golding, J., (2020). Statement in support of the scientists, public health professionals, and medical professionals of China combatting COVID-19. Lancet. 395(10226):e42-3.

7. Chukwu, C.O. (2014). Online journalism and the changing nature of traditional media in Nigeria. International Journal of Africa Culture and Tradition 2(3), 1-9.

8. ECDC, (2020). Coronavirus disease 2019 (COVID-19) pandemic increased transmission in EU/EEA and the UK-seventh update. Available at www.ecdc.europa.eu, accessed on 17 th April, 2020.

9. Esposito, L. (2020). Coronavirus prevention steps that do or do not work. Available at www.healthusnews.com, accessed, 20 ${ }^{\text {th }}$ April, 2020.

10. Ezegwu, D. T., Ezeonyejiaku, N. P. \& Asodike, S. O. (2018). Newspaper framing of monkey pox outbreak and its influence in media audience perception in South-East region of Nigeria. MCC Journal. doi: 10.13140/RG.2229917.36324.

11. Fawole, O. P., Thomas, K. A. \& Ibitade, A.S. (2012). Framing avian influenza coverage by Nigerian newspapers. Journal of Media and Communication Studies, 4 (1). Doi: 10.5897/jmcs1 1084.

12. Fotheringham, A. (2020). Coronavirus: Why are rising in Spain. Available at www.aljazeera.com, accessed 17 $7^{\text {th }}$ April, 2020.

13. Goffman, E. (1974). Frame analysis: An essay on the organisation of experience. Cambridge, MA: Harvard University Press.

14. Ifijeh, M. (2020). Nigeria's Travel Ban and the Delayed Measure Against COVID-19. Avaliable at https://www.thisdaylive.com/ accessed 3rd May, 2020. 
15. Kazeem, M. (2020). Nigeria'sbiggest battle with coronavirus will be beating misinformation, avaliable at www.qz.com, acessed, 21st April, 2020.

16. Kogah, V. \& Nwadiaro, E. C. (2016). Lassa fever: Focus on medical/academic research and popular press depiction. Global Journal of Arts, Humanities and Social Sciences, 4(7), 29-36.

17. Medford, R. J., Saleh, S. N., Sumarsono, A., Perl, T. M., \& Lehmann, C. U. (2020). An" Infodemic": leveraging high-volume twitter data to understand public sentiment for the COVID-19 Outbreak. medRxiv.

18. Nwafor, K.A, Nwasum, C.J. \& Nkwuda J.I (2017). One country, two eras: Analysis of how three Nigerian newspapers framed President Goodluck Jonathan and Muhammadu Buhari's economic policies. The Nigeria Journal of Communication, 14(1); 197-224.

19. Nwakpu, E. S., Ezema, V. O., \& Ogbodo, J. N. (2020). Nigeria media framing of coronavirus pandemic and audience response. Health Promotion Perspectives, 10(3), 192-199

20. Nwankwo, S.U \& Orji-Egwu, A. O. (2017). The fight against lassa fever in Ebonyi State, Nigeria: A clash of the people's culture and broadcast media campaign. Journal of communication and English 2 (1), 159-180.

21. Nsude, I. Nwamini, S. Onu, C. \& Nwofe, E. (2016). Politics of boko haram insurgency reportage during the 2015 general election in Nigeria. Middle-East Journal of Scientific Research, 24(8), 2473 2479.

22. NCDC. (2020). First case of coronavirus disease confirmed in Nigeria. Nigerian Centre for Disease Control (NCDC), 28 April. Retrieved 9 April, 2020.

23. Odoemelam, C. \&Okoro, C.N, (2013). Print media framing of boko haram insurgence in Nigeria: A Content Analytical Study of the Guardian, Daily Sun, Vanguard and ThisDay Newspapers. Journal of Research on Humanities and Social Sciences, 3(11), 86-94.

24. Ogbodo, J.N., Onwe, E.C, Chukwu, J., Nwasum, C.J., Nwakpu, E.S., Nwankwo, S.U., Nwamini, C., Elem, S., \& Ogbaeja, N.I. (2020). Communicating health crisis: a content analysis of global media framing of COVID-19. Health Promotion Perspectives, 2020, 10(3), 257-269.

25. Ogbodo, J. N. (2018). Domestic media coverage of Boko Haram insurgency in Nigeria (Doctoral dissertation, University of Central Lancashire). Available at: https://Clok.Uclan.Ac.Uk/25389/.

26. Ogundola, O. J. (2013). Framing disability: A content analysis of newspapers in Nigeria. Media studies -theses-13, https://surface.syr.edu/ms-thesis/15. 
27. Olajide, F.T. (2011). The internet and journalism practice in Nigeria. Global Journal of Human Social Science, 11(10), 15-20.

28. Oso, L. (2017). Understanding framing theory. Available at www.researchgate.net, accessed, April 24 ${ }^{\text {th }}, 2020$.

29. Philipp, S. (2010). Relations between Media: In The Johns Hopkins Guide to Digital Media. Ed. Lori, E. Marie-Laure, available at books.google.com.

30. Regencia, T. Stepansky, J. \& Uras, U. (2020). Coronavirus Cases in US Go Past 300,000, available at www.aljazeera.com, accessed $17^{\text {th }}$ April, 2020.

31. Riffe, D. Aust, C. \& Lacy, S. (1993). The effectiveness of random consecutive day and constructed week sampling in newspaper content analysis. Journalism Quarterly, 70(4), 133-139.

32. Scott, D. (2020). Coronavirus is exposing all of the weaknesses in the US health system. Accessed at www.vox.com, on $18^{\text {th }}$ April, 2020.

33. Secheufele, D. A. (1999). Framing as a theory of mass media effects. Journal of Communication (internet), 1999; 49:103-122.

34. Suleiman, J., \& Ojomo, O. (2019). The Political Economy of News Reporting and Poverty in Nigeria. European Scientific Journal, ESJ, 15(22), 213. https://doi.org/10.19044/esj.2019.v15n22p213

35. Russon, M.A. (2020). How Internet Access is improving in Nigeria. Available at www.bbc.com, accessed, 23 ${ }^{\text {rd }}$ April, 2020.

36. Tiyambe, P.Z. (2020). The Coronavirus; The political economy of a pathogen, available at www.theelephant.info. Accessed, 23 ${ }^{\text {rd }}$ April, 2020. 